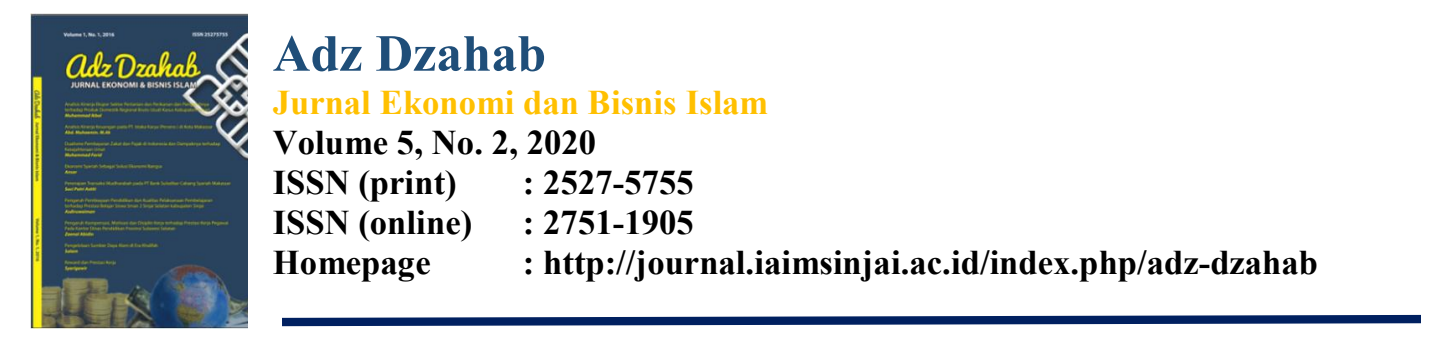

\title{
PERLINDUNGAN KONSUMEN TERHADAP JUAL BELI ONLINE (SUATU KAJIAN UUPK, ETIKA BISNIS ISLAM DAN HUKUM ISLAM)
}

\author{
Rahman Subha $^{1}$, Disa Nusia Nisrina ${ }^{2}$ Nurwahida $^{3}$ Muh.Rifai $^{4}$ \\ ${ }^{\text {I} Y a y a s a n ~ P e n d i d i k a n ~ A r-R a h m a n ~ A r-R a h i m ~ S u l-S e l ~ I n d o n e s i a, ~ J l . ~ M e s j i d ~ R a y a ~ N o . ~ 22 A, ~ G o w a ~}$ \\ ${ }^{2}$ (UIN) Alauddin Makassar, Jl. Yasin Limpo No. 36Gowa \\ ${ }^{3}$ Institut Agama Islam Muhammadiyah Sinjai, Sinjai \\ ${ }^{4}$ Institut Agama Islam Muhammadiyah Sinjai, Sinjai \\ KorespondesiPenulis. E-mail \\ ${ }^{1}$ rahmansyubha31@gmail.com/082393650218 \\ : ${ }^{2}$ disanusianisrinagmail.com/089526774850 \\ ${ }^{3}$ nurwahidarusdin19@gmail.com/082395174403
}

\begin{abstract}
Abstrak
Penelitian ini untuk mengkaji perlindungan konsumen terhadap jual beli online, dengan tinjauan undang-undang perlindungan konsumen (UUPK) dan hukum Islam. Menjawab permasalahan tersebut, penulis menggunakan pendekatan teologi normatif (syar'i) dan pendekatan yuridis normative dengan metode deskriptif-analitis. Setelah mengadakan pembahasan yang lebih mendalam bahwa jual beli online mengandung kemaslahatan dan efisiensi waktu termasuk yang pada dasarnya mubah (boleh) jumhur ulama memperbolehkan atas dasar suka sama suka, yang diqiyaskan dengan jual beli melalui surat dan perantara selama dilakukan atas dasar prinsip kejujuran dan kerelaan, serta tidak mengandung unsur-unsur yang diharamkan ataupun tidak mengandung unsureunsur yang dapat merugikan salah satu pihak. Sedangkan, pada pasal 4 UUPK mengandung pengaturan, nilai, dan tujuan, hak-hak konsumen yang sama dengan tujuan hukum Islam baik peran dan fungsi dalam upaya melindungi konsumen. Hukum Islam dan UUPK telah menekankan asas keseimbangan antara pelaku usaha dan konsumen yang dimaksudkan untuk memberikan keseimbangan diantara keduanya, yaitu antara penjual dan pembeli dalam jual beli yang mereka lakukan.
\end{abstract}

Kata Kunci: Perlindungan Konsumen - Jual Beli Online - UUPK - Hukum Islam

\section{Abstract}

This research is to examine consumer protection against online buying and selling, with a review of consumer protection laws (UUPK) and Islamic law. Answering these problems, the author uses a normative theological approach (syar'i) and a normative juridical approach with descriptive-analytical methods. After conducting a more in-depth discussion that buying and selling online contains time benefit and efficiency, including what is basically permissible (permissible) the number of scholars allows on a consensual basis, which is done by buying and selling through letters and intermediaries 


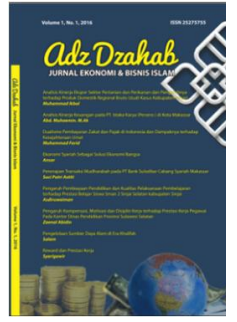

Adz Dzahab

Jurnal Ekonomi dan Bisnis Islam

Volume 5, No. 2, 2020

ISSN (print) : 2527-5755

ISSN (online) : 2751-1905

Homepage : http://journal.iaimsinjai.ac.id/index.php/adz-dzahab

as long as it is carried out on the basis of honesty and willingness principles and does not contain elements that are prohibited or do not contain elements that can harm either party. Meanwhile, Article 4 of the UUPK contains regulations, values, and objectives, consumer rights that are the same as the objectives of Islamic law, both roles and functions in protecting consumers. Islamic law and the UUPK have emphasized the principle of balance between business actors and consumers which is intended to provide a balance between the two, namely between the seller and the buyer in the sale and purchase they do.

Keywords: Consumer Protection - Buying and Selling Online - UUPK - Islamic Law

\section{Pendahuluan}

Muamalah adalah tukar-menukar barang atau sesuatu yang memberi manfaat dengan cara yang ditentukan, seperti jual beli, sewa-menyewa, upah-mengupah, pinjammeminjam, urusan bercocok tanam, berserikat, dan usaha lainnya. Agama telah memberikan aturan terhadap masalah muamalah ini untuk kemaslahatan umum. Dengan teraturnya muamalah, maka kehidupan manusia jadi terjamin dengan sebaik-baiknya dan teratur tanpa adanya penyimpangan-penyimpangan yang merugikannya.

Perilaku ekonomi ini sudah terbentuk sejak manusia sudah mulai membutuhkan individu lain yang memiliki barang atau jasa yang tidak dimilikinya, sedangkan ia membutuhkannya ataupun menginginkannya. Bentuk jual beli ini berkembang sesuai dengan perkembangan masyarakat dan perubahan sosial. Dalam masyarakat primitif jual beli mengambil bentuk tukar menukar barang yang tidak sejenis. Namun sistem jual beli ini perlahan ditinggalkan setelah mereka mengenal uang sebagai alat tukar-menukar.

Meski tradisi jual beli secara konvensional ini ditinggalkan, tetapi kata Fath alDuraini guru besar fikih Universitas Damaskus Syiria ini mengatakan bahwa esensi jual beli seperti ini masih berlaku, sekalipun untuk menentukan jumlah barang yang ditukar tetap diperhitungkan dengan nilai mata uang tertentu. Misalnya di Indonesia membeli spare part kendaraan ke Jepang, maka barang yang diimpor itu dibayar dengan minyak bumi dalam jumlah tertentu sesuai dengan nilai spare part yang diimpor di Indonesia itu (Nasrun Haroen, 2000:112).

Seiring dengan perkembangan kebudayaan dan tekhnologi, jual beli yang dulunya hanya barter, yaitu pertukaran barang satu dengan barang lain, lalu kemudian jual beli berubah sampai hari ini perubahan terus berlangsung hingga manusia sudah mulai merubah kebiasaan jual beli dari yang terlihat secara fisik ke sistem online.

Dengan kemajuan komunikasi dan informasi, telah membawa dampak pada kemajuan dalam dunia bisnis. Jual beli jarak jauh sudah merupakan kebiasaan yang berlaku di dunia bisnis saat ini. Dalam hal ini penjual dan pembeli tidak memperhatikan lagi masalah ijab qabul secara lisan, tetapi cukup dengan perantaraan kertas-kertas berharga, seperti cek, wesel, dan sebagainya. Kecuali itu kehadiran fisik dalam satu tempat (satu majelis) tidak lagi berlaku, karena cukup dengan misalnya via telepon dan internet (Sofyan AP., 2007:1).

Transaksi perdagangan seperti ini dimana hubungan antar manusia memasuki wilayah hubungan dagang atau bisnis, suatu transaksi bisnis (commerce) yang tidak lagi dilakukan secara langsung (konvensional) melainkan dapat pula dilakukan melalui jasa layanan internet dan teknologi internet ini dikenal dengan nama electronic commerce atau lebih popular dengan sebutan e-commerce.

Dampak yang signifikan adalah tersingkirnya jejak kertas yang sebelumnya merupakan bagian tak terpisahkan dari transaksi konvensional. Transaksi elektronik atau 


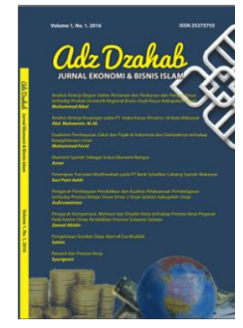

Adz Dzahab

Jurnal Ekonomi dan Bisnis Islam

Volume 5, No. 2, 2020

ISSN (print) : 2527-5755

ISSN (online) : 2751-1905

Homepage : http://journal.iaimsinjai.ac.id/index.php/adz-dzahab

e-commerce ini bisa diartikan sebagai setiap kegiatan perdagangan yang transaksinya terjadi seluruh atau sebagian di dunia maya, misalnya: penjualan barang dan jasa melalui internet, periklanan secara online, pemasaran, pemesanan, dan pembayaran secara online (Rif'ah Roihanah, 2011:100).

Transaksi dalam e-commerce ini sangat riskan, terutama jika pihak konsumen memiliki kewajiban melakukan pembayaran terlebih dahulu, sementara konsumen sendiri tidak dapat melihat kebenaran adanya barang yang dipesan ataupun kualitas barang pesanan tersebut. Lebih jauh lagi, pembayaran pun dapat dilakukan secara elektronik baik melalui transfer bank atau lewat pengisian nomor kartu kredit di dalam internet. Hal ini sangat mengganggu hak konsumen, khususnya terhadap hak untuk mendapatkan keamanan serta hak untuk mendapatkan informasi yang benar, jelas, dan jujur atas produk yang diberikan oleh penjual atau pelaku usaha tersebut.

Dengan telah dikeluarkan undang-undang tentang perlindungan konsumen dan UU ITE dalam upaya melindungi hak-hak konsumen transaksi e-commerce, setidaknya hal ini diharapkan dapat mendidik masyarakat Indonesia yang melakukan transaksi bisnisnya melalui e-commerce untuk lebih menyadari akan segala hak-hak dan kewajiban-kewajibannya yang dimiliki, dan pula hak dan kewajiban pelaku usaha seperti dapat dibaca dari konsideran undang-undang ini dimana dikatakan bahwa untuk meningkatkan kesadaran, pengetahuan, kepedulian, kemampuan, dan kemandirian konsumen untuk melindungi dirinya, serta menumbuh kembangkan sikap pelaku usaha yang bertanggung jawab (Gunawan Widjaja, 2000:1-2). Berdasarkan latar belakang yang telah penulis paparkan di atas, maka dapat dirumuskan permasalahan sebagai berikut:

1. Bagaimanakah tinjauan hukum Islam terhadap jual beli online?

2. Bagaimanakah perlindungan konsumen terhadap jual beli online dalam undangundang perlindungan konsumen (UUPK) dan relevansinya dengan Etika bisnis Islam dan hukum Islam?

\section{Metode}

\subsection{Jenis dan Pendekatan Penelitian}

Jenis penelitian ini meliputi kombinasi antara penelitian pustaka (library research) dengan metode kualitatif (qualitative method) (lexi J. Moleong, 2010:6).. Sedangkan Pendekatan yang digunakan dalam penelitian ini adalah pendekatan teologi normatif (syar'i), yaitu pendekatan yang digunakan untuk mengkaji dalil-dalil dari AlQur'an dan Hadits serta pendapat para ulama yang terkait dengan jual beli. Pendekatan yuridis normatif, yaitu pendekatan yang digunakan untuk mengkaji bagaimana relevansi jual beli online dalam hukum Islam terhadap undang-undang perlindungan konsumen.

\subsection{Metode Pengumpulan Data}

Metode pengumpulan data yang digunakan dalam penelitian ini adalah kepustakaan (library research), yaitu peneliti akan mengkaji pokok masalah melalui literatur-literatur atau referensi-referensi yang berkaitan dan relevan dengan judul penelitian ini.

\subsection{Instrumen Penelitian}

Adapun alat-alat yang akan mendukung penelitian ini adalah:

a. Buku memo, yaitu salah satu yang digunakan peneliti sebagai media pencatatan beberapa kutipan dari literatur ataupun hasil interview agar lebih memudahkan peneliti untuk mengumpulkan data;

b. Alat tulis, seperti pulpen atau pensil digunakan peneliti untuk merekam informasi dalam bentuk tulisan guna melaksanakan penelitian;

c. Notebook atau komputer jinjing, yaitu instrumen terpenting dalam proses penelitian ini. Mengingat kegunaannya yang multifungsi serta praktis, maka peneliti 


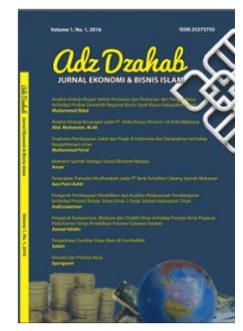

Adz Dzahab

Jurnal Ekonomi dan Bisnis Islam

Volume 5, No. 2, 2020

ISSN (print) : 2527-5755

ISSN (online) : 2751-1905

Homepage : http://journal.iaimsinjai.ac.id/index.php/adz-dzahab

menggunakan instrumen ini dalam berbagai kepentingan yang dianggap perlu selama

proses penelitian berlangsung.

\subsection{Teknik Pengolahan dan Analisis Data}

Setelah mengumpulkan beberapa data melalui sumber-sumber referensi (buku, jurnal, internet, wawancara), peneliti mengklarifikasikan data tersebut dan kemudian akan menggunakan penelitian bersifat deskriptif analisis, yaitu metode yang dilakukan untuk memecahkan masalah dengan jalan mengumpulkan data, menyusun, mengklarifikasikan serta menganalisis kemudian menguraikannya. Sehingga permasalahan mengenai penelitian ini dideskripsikan berdasarkan data yang diperoleh kemudian dianalisis sebagai sebuah gagasan yang menarik untuk ditampilkan dalam kajian ini.

Secara sistematis proses analisis data peneliti lakukan melalui tiga tahapan secara berkesinambungan, yaitu mereduksi data, penyajian data dan kesimpulan atau verifikasi data. Adapun penjelasannya sebagai berikut: (1) Reduksi data, yaitu proses pengumpulan data yang kemudian dilakukan pemilahan, diklasifikasi, serta pemusatan perhatian pada penyederhanaan data. Karena itu data yang diambil adalah data-data yang berkaitan dengan permasalahan yang diteliti. Penelitian ini hanya berkaitan dengan perilaku konsumsi yang dilakukan oleh Mahasiswi UIN Alauddin Makassar terhadap penggunaan kosmetik pemutih. (2) Penyajian data, yaitu menyajikan data yang sudah disaring dan diorganisasikan secara keseluruhan dalam betuk naratif deskriptif. Dalam penyajian data dilakukan interprestasi terhadap hasil data yang ditemukan, sehingga kesimpulan yang dirumuskan menjadi lebih objektif. (3) Penarikan kesimpulan atau verifikasi data yaitu merumuskan kesimpulan setelah melakukan tahap reduksi dan penyajian data secara induktif untuk menjawab rumusan masalah. Ketiga alur kegiatan analisis data ini saling terkait dalam proses penyimpulan hasil akhir peneliti

\section{Hasil dan Pembahasan}

\subsection{Rukun Jual-Beli}

Suatu jual beli dapat dikatakan sah apabila telah memenuhi rukun dan syarat yang telah ditentukan oleh syara'. Mengenai rukun dan syarat jual beli, para ulama berbeda pendapat. Dalam menentukan rukun jual beli ini terdapat perbedaan pendapat ulama mazhab Hanafi dan jumhur ulama. Menurut ulama mazhab Hanafi, orang yang berakad, barang yang dibeli, dan nilai tukar barang termasuk dalam syarat jual beli, bukan rukun.

Rukun jual beli menurut ulama mazhab Hanafi hanya satu, yaitu ijab dan kabul. Menurut mereka, yang menjadi rukun dalam jual beli itu hanyalah kerelaan (keridaan) kedua belah pihak untuk berjual beli. Namun karena unsur kerelaan itu merupakan unsur hati yang sering tidak kelihatan, maka diperlukan indikator yang menujukkan kerelaan tersebut dari kedua belah pihak. Indikator ini bisa tergambar dalam ijab dan kabul, atau melalui cara saling memberikan barang dan harga barang (Abdul Azis Dahlan, 1996: 28). Hal ini berbeda dengan pendapat jumhur ulama yang menyatakan bahwa rukun jual beli itu ada empat, yaitu:

a. Orang yang berakad (penjual dan pembeli);

b. Sighat (lafal ijab dan kabul);

c. Ada barang yang dibeli;

d. Ada nilai tukar pengganti barang.

Para ulama fikih sepakat menyatakan bahwa suatu jual beli baru bersifat mengikat apabila jual beli baru bersifat mengikat apabila jual beli tersebut terbebas dari segala macam khiyar (hak pilih untuk meneruskan atau membatalkan jual beli). Apabila jual beli itu masih mempunyai hak khiyar, maka jual beli itu belum mengikat dan masih bisa dibatalkan. Apabila syarat itu terpenuhi secara hukum, maka jual beli itu dianggap 


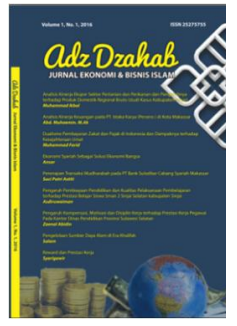

Adz Dzahab

Jurnal Ekonomi dan Bisnis Islam

Volume 5, No. 2, 2020

ISSN (print) : 2527-5755

ISSN (online) : 2751-1905

Homepage : http://journal.iaimsinjai.ac.id/index.php/adz-dzahab

sah sah dan mengikat. Karena itu pihak penjual dan pembeli tidak boleh lagi membatalkan jual beli tersebut.

\subsection{Etika Jual-Beli}

Etika penting untuk membuat jual beli menjadi berkah. Salah satu sumber rujukan etika dalam jual beli adalah etika yang bersumber dari Rasulullah saw. beliau telah mengajarkan beberapa etika dalam berjualbeli sesuai syariat, diantaranya: (Malahayati, 2010:4)

a. Jujur dalam menjelaskan produk. Kejujuran merupakan syarat fundamental dalam kegiatan jual beli. Rasulullah saw. sangat intens menganjurkan kejujuran dalam aktivitas jual beli. Dalam hal ini Rasulullah saw. bersabda yang artinya: "Tidak dibenarkan seorang muslim menjual satu jualan yang mempunyai aib, kecuali ia menjelaskan aibnya." (HR. Al-Quzwani). Rasulullah saw. sendiri selalu bersikap jujur dalam jual beli. Beliau melarang para pedagang meletakkan barang busuk disebelah bawahdan barang yang baru dibagian atas. Ini termasuk perbuatan menipu pembeli;

b. Suka sama suka. Permintaan dan penawaran haruslah terjadi suka sama suka dan tidak ada yang merasa terpaksa dengan harga tersebut. Disinilah kemudian berlaku hak memilih, yaitu hak pilih bagi salah satu atau kedua belah pihak yang melaksanakan transaksi untuk melangsungkan atau membatalkan transaksi untuk melangsungkan atau membatalkan transaksi yang disepakati sesuai dengan kondisi masing-masing pihak yang melakukan transaksi;

c. Tidak menipu takaran, ukuran, dan timbangan. Dalam perdagangan, timbangan yang benar dan tepat harus benar-benar diutamakan. Tidak menimbun barang (ihtikar). Ihtikar ialah menimbun barang (menumpuk dan menyimpan barang pada masa tertentu, dengan tujuan agar harganya suatu saat menjadi naik dan keuntungan besar pun diperoleh). Rasulullah saw. melarang keras perilaku jual beli semacam itu. Misalnya, penumpukan BBM agar ketika mahal, penjual akan mendapatkan keuntungan besar;

f. Tidak melakukan monopali. Salah satu keburukan sistem ekonomi kapitalis ialah memperbolehkan monopoli. Contoh yang sederhana adalah penguasaan individu tertentu atas hak milik sosial, seperti air, udara, tanah, dan kandungan isinya seperti barang tambang dan mineral. Orang seprti ini hanya memikirkan kepentingan pribadinya saja. Inilah yang dilarang keras dalam Islam;

g. Mengutamakan kepuasan pelanggan. Ketekunan dan kesungguhan Rasulullah saw. dalam bisnis jual beli sangat menonjol. Beliau pernah menunggu pembelinya, Abdullah bin Hamzah selama tiga hari. Abdullah bin hamzah mengatakan: "Aku telah membeli sesuatu dari Nabi sebelum beliau menerima tugas kenabian, dank karena masih ada suatu urusan dengannya, maka menjanjikan untuk mengantarkan padanya, tetapi aku lupa. Ketika teringat tiga hari kemudian, aku pun pergi ke tempat tersebut dan menemukan Nabi masih berada disana. Nabi berkata, 'engkau telah membuatku resah, aku berada disini selama tiga hari menunggumu'.” (HR. Abu Dawud);

h. Teguh menjaga amanah. Islam menginginkan seorang pebisnis muslim mempunyai hati yang tanggap dengan menjaganya dan memenuhi hak-hak Allah dan manusia, serta menjaga muamalahnya dari unsur yang melampaui batas atau sia-sia. Dia tidak akan mengingkari janjinya kepada pelanggan, sehingga membuat mereka kecewa dan berbalik;

k. Toleran. Toleran membuka kunci rezeki dan saran hidup tenang,. Manfaat toleran adalah mempermudah pergaulan, mempermudah urusan jual beli, dan mempercepat kembalinya modal. Allah swt. mengasihi orang yang lapang dada dalam menjual, dalam membeli, serta melunasi utang. 


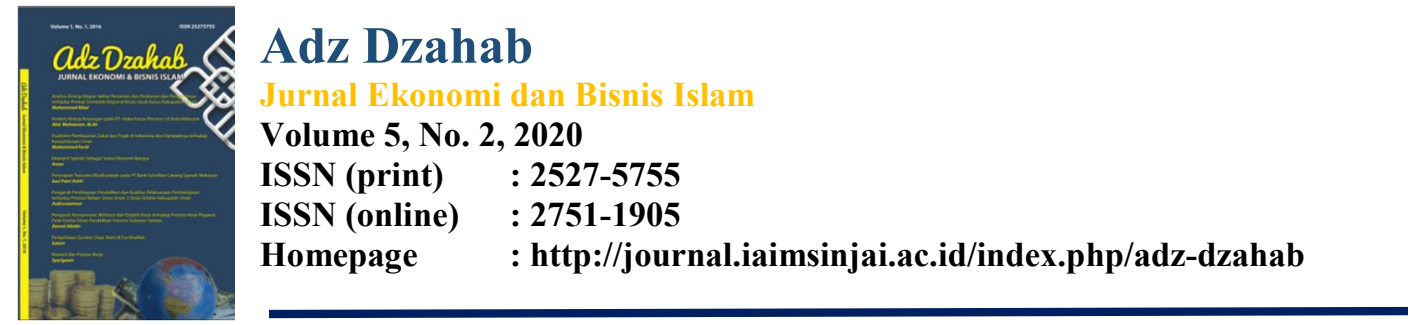

\subsection{Jenis dan Mekanisme Transaksi Jual Beli Online}

Konsumen jual beli online semakin dituntut untuk mengetahui lebih dalam mengenai proses, resiko serta keamanan dari sebuah transaksi online. Saat ini jenis transaksi online juga semakin beragam mulai dari jenis konvensional dimana pembeli dan penjual harus bertatap muka dalam melakukan proses transaksi hingga yang menggunakan proses transaksi otomatis tanpa harus bertatap muka. Di Indonesia sendiri ada beberapa jenis transaksi jual beli online yang biasa dilakukan oleh konsumen jual beli online, yaitu:

\section{1) Transfer Antar Bank}

Transaksi dengan cara transfer antar bank merupakan jenis transaksi yang paling umum dan popular digunakan oleh para pelaku usaha atau penjual online. Jenis transaksi ini juga memudahkan proses konfirmasi karena dana bisa dengan cepat di cek oleh penerima dana atau penjual. Prosesnya adalah pertama-tama konsumen mengirim dana yang telah disepakati lalu setelah dana masuk, maka penjual akan mengirimkan barang transaksi yang dijanjikan.

\section{2) COD (Cash On Delivery)}

Pada sistem COD sebenarnya hampir dapat dikatakan bukan sebagai proses jual beli secara online, karena penjual dan pembeli terlibat secara langsung, bertemu, tawarmenawar, dan memeriksa kondisi barang baru kemudian membayar harga barang. Keuntungan dari sistem ini adalah antara pelaku usaha dan konsumen lebih bisa leluasa dalam proses transaksi. Konsumen bisa melihat dengan detil barang yang akan dibeli. Jenis transaksi ini dipopulerkan oleh website jual beli seperti Tokobagus, Berniaga, dan lainnya. Kekurangan dari sistem ini adalah keamanan baik pelaku usaha maupun konsumen karena boleh jadi pihak yang akan ditemui pelaku usaha atau konsumen adalah orang yang berniat jahat.

3) Kartu Kredit

Kartu kredit merupakan alat pembayaran yang semakin popular, selain memberikan kemudahan dana proses verifikasi, pembeli juga tidak perlu melakukan semua tahap transaksi. Akan tetapi karena tidak semua pembeli mempunyai kartu kredit sehingga cara pembayaran ini menjadi pilihan kedua. Bahkan pengguna dengan kartu kredit pun akan berusaha memastikan bahwa toko si pelaku usaha memiliki tingkat keamanan yang tinggi guna menghindari tindakan pencurian data oleh pihak-pihak tertentu.

\section{Rekening Bersama}

Jenis transaksi ini disebut juga dengan istilah escrow. Cara pembayaran ini mempunyai perbedaan dengan proses pembayaran melalui transfer bank. Jika dalam transfer bank pihak ketiganya adalah bank, sedangkan dengan sistem rekening bersama yang menjadi pihak ketiga adalah lembaga pembayaran yang telah dipercaya baik oleh pihak pelaku usaha maupun konsumen. Prosesnya, yaitu pertama konsumen mentransfer dana ke pihak lembaga rekening bersama. Setelah dana dikonfirmasi masuk, lalu pihak rekening bersama meminta pelaku usaha mengirim barang yang sudah disepakati. Jika barang sudah sampai, baru dana tersebut diberikan pada si pelaku usaha.

Dengan sistem ini dana yang diberikan oleh pembeli bisa lebih terjamin keamanannya karena dananya hanya akan dilepas jika barang benar-benar sudah sampai ditangan konsumen. Jika terjadi masalah pun dana bisa ditarik oleh sang konsumen. Sistem ini banyak digunakan pada proses jual beli antar member forum Kaskus.

\section{Potongan Pulsa}




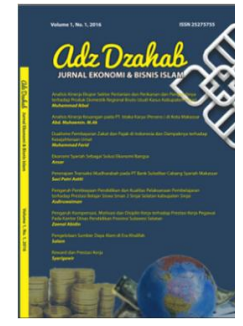

Adz Dzahab

Jurnal Ekonomi dan Bisnis Islam

Volume 5, No. 2, 2020

ISSN (print) : 2527-5755

ISSN (online) : 2751-1905

Homepage : http://journal.iaimsinjai.ac.id/index.php/adz-dzahab

Metode pemotongan pulsa biasanya diterapkan oleh toko online yang menjual produk-produk digital seperti aplikasi, musik, ringtone, dan permainan. Transaksi ini masih didominasi oleh transaksi menggunakan perangkat seluler atau smartphone.

Dalam mekanisme jual beli online hal pertama yang dilakukan oleh konsumen, yaitu mengakses situs tertentu dengan cara masuk ke alamat website toko online yang menawarkan penjualan barang. Setelah masuk dalam situs itu, konsumen tinggal melihat menunya dan memilih barang apa yang ingin dibeli. Misalnya, jam tangan, klik jam tangan, merek apa yang disukai, klik dan pilih harga yang cocok, lalu klik sudah cocok, bisa lakukan transaksi dengan menyetujui perjanjian yang telah ditetapkan oleh kedua belah pihak. Kalau sudah terjadi kesepakatan secara digital, pelaku usaha akan mengirimkan nomor rekening dan alamatnya pada konsumen dan setelah itu konsumen menunggu barangnya sekitar seminggu (Misbahuddi, 2020:242).

Adapun saat ini dengan berbagai macamnya sosial media seperti facebook, Line, Black Berry Massanger (BBM), dan lainnya. Konsumen tinggal melihat postingan pelaku usaha berupa gambar-gambar produk yang ditawarkan kepada konsumen, lalu kemudian konsumen tinggal mengkonfirmasi lewat komentar, inbox atau sms dan telepon jika ingin memesan barang yang di inginkan. Biasanya digambar itu telah tertera nomor rekening pelaku usaha, sehingga setelah mengkonfirmasi pelaku usaha, maka konsumen bisa langsung mentransfer uangnya lewat bank, lalu mengirimkan bukti transfernya ke pelaku usaha, setelah itu konsumen menunggu barang yang dibelinya paling cepat biasanya dalam waktu seminggu.

\subsection{Hak-Hak Konsumen}

Dalam hukum Islam, upaya untuk memberikan perlindungan terhadap konsumen, pembeli mempunyai hak khiyar, yaitu hak yang istimewa berupa diberikan kepada pihak-pihak yang melakukan transaksi untuk meneruskan atau membatalkannya. Diantaranya, yaitu:

\section{1) Khiyar Majelis}

Antara penjual dan pembeli boleh memilih akan melanjutkan jual beli atau akan membatalkannya. Selama keduanya masih ada dalam satu tempat (majelis), khiyar majelis boleh dilakukan dalam berbagai jual beli. Rasulullah saw bersabda Diriwayatkan Ibnu Umar ra. katanya: Sesungguhnya Rasulullah saw. pernah bersabda: "Penjual dan pembeli, masing-masing mempunyai hak khiyar yaitu kesempatan berpikir selagi mereka belum berpisah melainkan jual beli khiyar.

2) Khiyar 'Aib

Yaitu hak pilih dari kedua belah pihak yang melakukan akad, apabila terdapat suatu cacat pada benda yang diperjual belikan dan cacat itu tidak diketahui pemiliknya pada saat akad berlangsung. Dalam jual beli ini disyaratkan kesempurnaan benda-benda yang dibeli, seperti seseorang berkata; "saya beli mobil itu dengan harga sekian, bila mobil itu ada cacatnya akan saya kembalikan," seperti yang diriwayatkan oleh Ahmad dan Abu Dawud dari Aisyah r.a. bahwa seseorang membeli budak, kemudian budak tersebut disuruh berdiri didekatnya, didapatinya pada diri budak itu kecacatan lalu diadukannya kepada Rasul, maka budak itu dikembalikan pada penjual. Hal ini juga sebagaimana sabda Rasulullah saw. dari Uqabah bin Amir bahwa seorang muslim adalah saudara muslim lainnya. Tidak halal bagi seorang muslim menjual sesuatu kepada saudaranya, sementara didalamnya terdapat cacat, kecuali ia menjelaskannya (HR. Ahmad, Ibnu Majah, Tabrani) (Zulham, 2013:60).

3) Khiyar Syarat

Ditetapkan bagi salah satu pihak yang berakad atau keduanya, apakah meneruskan atau membatalkan akad selama dalam tanggung waktu yang disepakati 


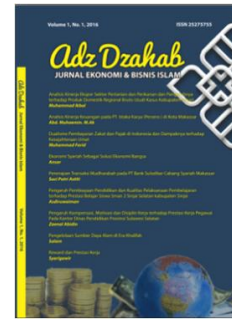

Adz Dzahab

Jurnal Ekonomi dan Bisnis Islam

Volume 5, No. 2, 2020

ISSN (print) : 2527-5755

ISSN (online) : 2751-1905

Homepage : http://journal.iaimsinjai.ac.id/index.php/adz-dzahab

bersama. Seperti seseorang berkata: "Saya beli barang ini dari engkau dengan syarat saya berhak memilih meneruskan atau membatalkan akad selama tiga hari." Sebagaimana Rasulullah saw. bersabda yang artinya: "Kamu boleh khiyar pada setiap benda yang telah dibeli selama tiga hari tiga malam." (HR. Baihaqi).

4) Khiyar at-Ta'yin

Hak pilih bagi pembeli dalam menentukan barang yang berbeda kualitas dalam jual beli. Mislanya, dalam pembelian keramik ada yang berkualitas super dan sedang. Akan tetapi, pembeli tidak mengetahui secara pasti mana keramik yang berkualitas A dan mana keramik yang berkualitas B. Untuk menentukan pilihan tersebut ia memerlukan bantuan ahli keramik atau arsitek. Misalnya juga, seseorang membeli empat ekor kambing dari sekumpulan binatang, maka pembeli diberi hak khiyar ta'yin sehingga ia dapat menentukan empat ekor kambing yang ia inginkan diantara sekumpulan kambing itu.

5) Khiyar ar-Ru'yah

Hak pilih bagi pembeli untuk menyatakan berlaku atau batalnya jual beli yang dilakukannya terhadap suatu objek yang belum dilihatnya saat berlangsungnya akad. Jika pembeli kemudian melihat barang tersebut dan tidak berhasrat terhadapnya, atau pembeli melihat barang tersebut tidak sesuai dengan keinginannya, maka pembeli berhak menarik membatalkan diri dari akad jual beli tersebut. Rasulullah saw. bersabda yang artinya: "Siapa yang membeli sesuatu yang belum ia lihat, maka ia berhak khiyar apabila telah melihat barang itu." (HR. Daruqutni dari Abu Hurairah).

Sedangkan hak-hak konsumen diatur dalam pasal 4 Undang-undang No.8 Tahun 1999 tentang Perlindungan Konsumen, yaitu:

a. Hak atas kenyamanan, keamanan, dan keselamatan dalam mengkonsumsi barang atau jasa;

b. Hak untuk memilih barang atau jasa serta mendapatkan barang atau jasa tersebut sesuai dengan nilai tukar dan kondisi serta jaminan yang dijanjikan; c. Hak atas informasi yang benar, jelas, dan jujur mengenai kondisi dan jaminan barang atau jasa;

d. Hak untuk didengar pendapat dan keluhannya atas barang atau jasa yang digunakan;

e. Hak untuk mendapatkan advokasi, perlindungan, dan upaya penyelesaian sengketa perlindungan konsumen secara patut;

f. Hak untuk mendapat pembinaan dan pendidikan konsumen;

g. Hak untuk diperlakukan atau dilayani secara benar dan jujur serta tidak diskriminatif;

h. Hak untuk mendapatkan kompensasi, ganti rugi atau penggantian, apabila barang atau jasa yang diterima tidak sesuai dengan perjanjian atau tidak sebagaimana mestinya;

i. Hak-hak yang diatur dalam ketentuan peraturan perundang-undangan lainnya.

\subsection{Problematika Rukun dan Syarat}

a) Orang yang bertransaksi

Dalam transaksi jual beli online, masing-masing pihak yang terlibat transaksi telah memenuhi kriteria tamyiz, dan telah mampu mengoperasikan komputer dan tentunya telah memenuhi ketentuan memiliki kecakapan yang sempurna dan mempunyai wewenang untuk melakukan transaksi dan hal ini tidak mungkin dilakukan oleh orang yang tidak memiliki kecakapan yang sempurna, seperti dilakukan oleh anak kecil yang belum berakal atau orang gila.

b) Shigat 


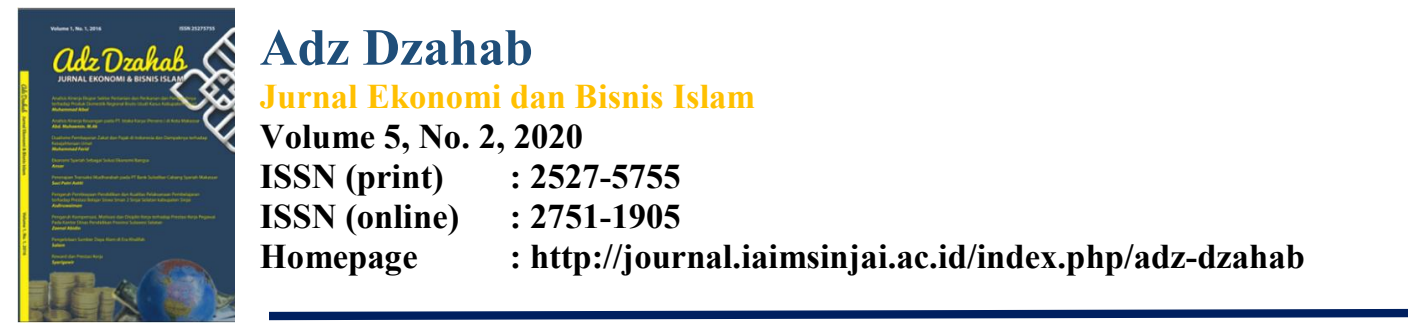

Sighat akad (ijab dan kabul) adalah sesuatu yang disandarkan dari dua pihak yang berakad yang menunjukkan atas apa yang ada dihati keduanya tentang terjadinya suatu akad. Wahbah al-Zuhaili memberi definisi akad dengan makna pertemuan ijab dan kabul yang dibenarkan oleh syara' yang menimbulkan akibat hukum terhadap objeknya (Ala' Eddin Kharofa, 1997:10), Ijab dan kabul dalam jual beli perantara, baik melalui orang yang diutus, maupun melalui media tertentu, seperti surat-menyurat, telepon. Ulama fikih telah sepakat menyatakan bahwa jual beli melalui perantara, baik dengan utusan atau melalui media tertentu adalah sah, apabila antara ijab dan kabul sejalan.

Dalam transaksi jual beli online, penjual dan pembeli bertemu dalam satu majelis, yaitu yang dinamakan majelis maya. Penjual dan pembeli tidak berada dalam satu tempat tertentu dalam arti secara fisik dan bisa saja transaksi dilakukan dari berbagai negara yang berbeda. Pada dasarnya, pernyataan kesepakatan pada transaksi jual beli online sama dengan pernyataan kesepakatan sebagaimana transaksi dalam hukum Islam. Pernyataan itu dapat dilakukan dengan berbagai cara dan melalui berbagai media, selama dapat dipahami maksudnya oleh penjual dan pembeli dan tentunya atas dasar kerelaan antara kedua pihak yang melakukan transaksi.

c) Objek Transaksi Jual Beli

Pada dasarnya, jual beli termasuk muamalah yang hukumnya dibolehkan, kecuali ada dalil yang mengharamkannya. Setelah mengkaji rukun dan syarat jual beli dalam hukum Islam, maka dapat ditarik kesimpulan bahwa transaksi jual beli online ini tidak bertentangan dengan hukum Islam, baik dari segi orang yang berakad, sighat (lafal ijab dan kabul), objek transaksi, dan nilai tukar barang, selama dalam transaksi itu tidak ada unsur haram, seperti riba, gharar (penipuan), bahaya, ketidakjelasan, dan merugikan hak orang lain, pemaksaan, dan tentunya barang atau jasa yang jadi objek transaksi adalah halal, bukan yang bertentangan dengan al-Qur'an dan Hadits, seperti narkoba, bangkai, babi, dan lain-lain sebagainya.

Selain itu, objek yang dijadikan komoditi dalam transaksi jual beli online, tidak berbeda dengan transaksi yang ada dalam hukum perikatan Islam, selama objek transaksi tersebut halal, bermanfaat, dan memliki kejelasan baik bentuk, fungsi dan keadaannya serta dapat diserahterimakan pada waktu dan tempat yang telah disepakati oleh penjual dan pembeli. Apabila objek jual beli online terdapat ketidaksesuaian antara apa yang ditampilkan dilayar internet atau handphone dengan barang yang telah diterima oleh pembeli, maka pembeli berhak khiyar, apakah ingin mengambil barang itu atau mengembalikannya kepada penjual.

Proses transaksi jual beli online, sebelum pembayaran dilakukan, masing-masing pihak penjual dan pembeli telah menyepakati mengenai jumlah dan jenis mata uang yang digunakan sebagai pembayaran serta metode pembayaran yang digunakan, misalnya dengan kartu kredit. Pada saat penjual dan pembeli telah mencapai kesepakatan, kemudian melakukan pembayaran melalui bank, dan setelah pembayaran telah diterima oleh penjual dan pembeli telah mengirimkan bukti pembayaran atau kuitansi pembelian, maka penjual mengirim barang sesuai dengan kesepakatan mengenai saat penyerahan dan spesifikasi barang kepada pembeli.

Pembayaran harga dalam transaksi jual beli online pada prinsipnya telah memenuhi ketentuan-ketentuan yang ada dalam sistem perikatan Islam. Pembayaran atau harga dalam transaksi jual beli online merupakan sesuatu yang bernilai dan bermanfaat. Uang yang digunakan sebagai alat pembayaran pengganti barang dapat ditentukan dan diketahui oleh pihak-pihak yang terlibat dalam transaksi dan dibayarkan sesuai kesepakatan penjual dan pembeli.

\subsection{Upaya Perlindungan Konsumen}




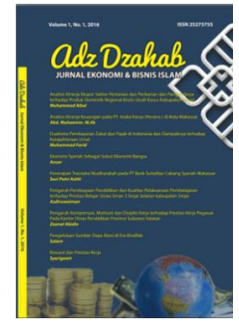

Adz Dzahab

Jurnal Ekonomi dan Bisnis Islam

Volume 5, No. 2, 2020

ISSN (print) : 2527-5755

ISSN (online) : 2751-1905

Homepage : http://journal.iaimsinjai.ac.id/index.php/adz-dzahab

Jual beli online, jika dilihat dari aspek maqashid syariah, terdapat kemaslahatan, berupa kemudahan transaksi, dan efisiensi waktu serta bersifat dinamis terhadap kemajuan pengetahuan dan teknologi. Karena memang syari'at Islam itu ditetapkan untuk kemaslahatan manusia baik didunia maupun diakhirat. Jual beli dalam hukum Islam juga tidak melihat dari segi jenis atau model sarana yang digunakan, tetapi lebih ditekankan pada prinsip moral seperti kejujuran dan prinsip kerelaan antara kedua belah pihak. Karena menjual barang yang cacat tanpa memberitahukan kepada pembeli tentu dicela oleh Islam.

Oleh sebab itu Islam menenkan untuk menerapkan i’tikad baik pelaku usaha dan konsumen dalam bertransaksi. Ketatnya hukum Islam dalam menentukan rukun dan syarat dalam jual-beli sehingga jika tidak terpenuhi merupakan jual-beli yang tidak sah itu merupakan upaya preventif dalam mengurangi terjadinya i tikad tidak baik dalam jual beli online.

UUPK dan hukum Islam memiliki relevansi dalam jual beli online yakni berkaitan dengan etika yaitu perilaku pelaku usaha dalam transaksi jual beli online, dimana pelaku usaha harus memberikan informasi yang benar, jelas, dan jujur terkait barang dan/atau jasa yang dijualnya sesuai dengan iklan yang dipaparkan melalui media internet. Sejalan dengan itu adalah terkait dengan hak-hak konsumen, yaitu dimana konsumen berhak memperoleh informasi yang benar, jelas, dan jujur mengenai barang dan/atau jasa yang dijual oleh pelaku usaha.

Baik UUPK maupun hukum Islam menekankan asas keseimbangan antara pelaku usaha dengan konsumen sebagai upaya awal melindungi hak-hak konsumen. Asas keseimbangan ini yakni memberikan keseimbangan antara pelaku usaha dan konsumen. Namun, dalam transaksi jual beli online, seringkali terjadi pelanggaran yang dilakukan oleh pelaku usaha, seperti adanya informasi yang tidak jelas mengenai produk atau barang yang dijual oleh pelaku usaha, baik jual beli secara langsung maupun melalui online. Sehingga konsumen merasa dirugikan karena barang yang dibeli tidak sesuai dengan yang diiklankan melalui media cetak maupun elektronik. Hal ini tentunya melanggar asas keseimbangan yang tercantum dalam UUPK terlebih lagi oleh hukum Islam. Secara garis besar, persamaan dan perbedaan antara UUPK dan hukum Islam terkait dengan hak dan kewajiban bagi pelaku usaha dan konsumen adalah sebagai berikut: (M. Yusrie,, 2009:19).

\begin{tabular}{|l|l|}
\hline \multicolumn{1}{|c|}{ UUPK } & \multicolumn{1}{|c|}{ HUKUM ISLAM } \\
\hline $\begin{array}{l}\text { Hak konsumen maupun pelaku usaha } \\
\text { bersifat mutlak ditentukan dalam } \\
\text { undang-undang atau UUPK }\end{array}$ & $\begin{array}{l}\text { Hak konsumen maupun pelaku } \\
\text { usaha tidak bersifat mutlak dan } \\
\text { ditentukan oleh syara }\end{array}$ \\
\hline $\begin{array}{l}\text { Hak informasi yang diterima } \\
\text { konsumen menyangkut dengan } \\
\text { kualitas dan kuantitas produk }\end{array}$ & $\begin{array}{l}\text { Hak informasi yang diterima } \\
\text { konsumen selain menyangkut } \\
\text { kualitas dan kuantitas, juga } \\
\text { termasuk informasi kehalalan } \\
\text { suatu produk }\end{array}$ \\
\hline $\begin{array}{l}\text { Hak konsumen dalam kebebasan } \\
\text { memilih barang diukur dengan nilai } \\
\text { tukar yang pantas terhadap suatu } \\
\text { produk }\end{array}$ & $\begin{array}{l}\text { Hak konsumen dalam kebebasan } \\
\text { memilih barang, selain diukur } \\
\text { dengan nilai tukar juga } \\
\text { mempertimbangkan hak orang lain } \\
\text { yang terlebih dahulu melakukan }\end{array}$ \\
\hline
\end{tabular}




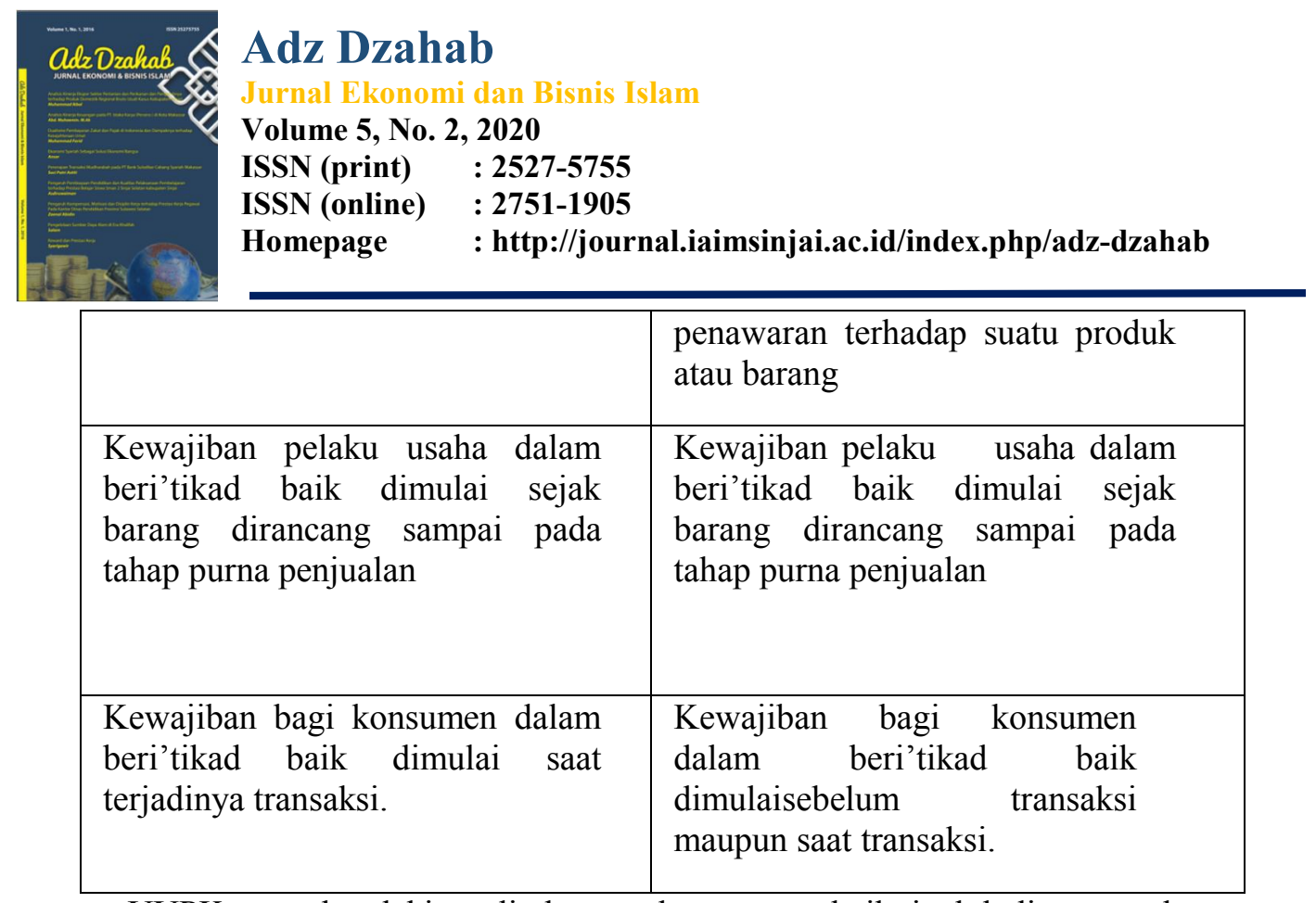

UUPK menghendaki perlindungan konsumen, baik jual beli secara langsung maupun jual beli secara online. UUPK dapat dijadikan sebagai instrumen hukum di pengadilan jika terjadi pelanggaran terhadap hak-hak konsumen yang terdapat pada pasal 4 UUPK selain daripada UU ITE. Begitu pula dengan hukum Islam dengan hak khiyarnya yang bertujuan untuk melindungi konsumen.

Perbedaan hukum Islam dan UUPK adalah pada penggunanaan istilah saja, antara lain khiyar majelis dengan hak untuk didengar, khiyar syarat dengan hak memilih, khiyar 'aib dengan hak atas kenyamanan, keamanan, dan keselamatan dalam mengkonsumsi barang dan hak atas informasi yang benar, jelas, dan jujur mengenai kondisi dan jaminan barang atau jasa, khiyar ta'yin dengan hak untuk memilih dan hak memperoleh keamanan, dan khiyar ru'yah dengan hak untuk didengar. Jika dikaji secara mendalam dari segi pengaturan, nilai, dan tujuan, hak-hak konsumen dalam hukum Islam dan UUPK memiliki peran dan fungsi yang sama dalam perlindungan hak-hak konsumen.

Transaksi jual beli online dan UUPK saling terkait karena dalam UUPK, pelaku usaha dituntut untuk tidak mengabaikan hak-hak konsumen dalam jual beli online. Meskipun masih ada kasus dimana pelaku usaha seringkali memberikan informasi yang menyesatkan kepada konsumen terkait dengan produk yang ia jual. Bahkan tidak sedikit pelaku usaha yang bertanggung jawab jika terjadi kesalahan. Dengan mengetahui dan memahami relevansi antara jual beli online menurut hukum Islam terhadap UUPK, maka tentunya kita akan lebih berhati-hati dan cermat saat bertransaksi melalui internet dan pelaku usaha juga hendaknya tidak mengabaikan hak-hak konsumen, dimana pelaku usaha seringkali melakukan kejahatan terhadap konsumen, sehingga dapat tercipta keseimbangan antara pelaku usaha dan konsumen.

\section{Kesimpulan}

Jual beli online termasuk aspek muamalah yang pada dasarnya mubah (boleh), kecuali ada dalil yang mengharamkannya. Selain itu, rukun dan syarat jual beli online juga tidak bertentangan dengan rukun dan syarat dalam sistem hukum perikatan Islam. Yang diharamkan dalam transaksi jual beli online, yaitu transaksi yang didalamnya terdapat unsur-unsur haram, seperti riba, gharar (penipuan), bahaya, ketidakjelasan, merugikan hak orang lain, pemaksaan, dan barang atau jasa yang menjadi objek transaksi adalah halal, bukan yang diharamkan seperti khamr, bangkai, babi, narkoba, judi online, dan sebagainya. Selain itu, transaksi jual beli online juga mengandung aspek kemaslahatan berupa kemudahan dan efisiensi waktu. Didalam fikih, ditemukan adanya kesepakatan ulama terhadap transaksi jual beli melalui surat dan perantara, sehingga jual beli online dapat dianalogikan sebagai jual beli melalui surat atau perantara selama 


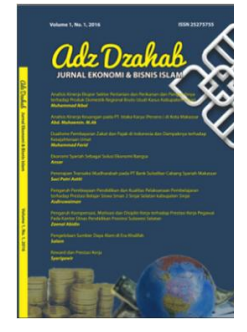

Adz Dzahab

Jurnal Ekonomi dan Bisnis Islam

Volume 5, No. 2, 2020

ISSN (print) : 2527-5755

ISSN (online) : 2751-1905

Homepage : http://journal.iaimsinjai.ac.id/index.php/adz-dzahab

dilakukan atas dasar prinsip kejujuran dan prinsip suka sama suka (kerelaan) dan keseimbangan dalam memenuhi hak dan kewajiban masing-masing dengan landasan i tikad baik. Sehingga baik UUPK dalam pasal 4 maupun hukum Islam melalui hak-hak khiyarnya menekankan asas keseimbangan antara pelaku usaha dengan konsumen. Asas keseimbangan ini dimaksudkan untuk memberikan perlindungan terhadap konsumen.

Daftar Pustaka

Dahlan, Abdul Azis, ed. Ensiklopedi Hukum Islam, jilid 3. Cet. I; Jakarta: PT Ichtiar Baru Van Hoeve, 1996.

Haroen, Nasrun. Fiqh Muamalah. Jakarta: Gaya Media Pratama, 2000.

Hendra S dan Tim Redaksi Jabal, ed., Sahih Bukhari Muslim: Hadits yang Diriwayatkan oleh Imam Bukhari dan Imam Muslim.

Kau, Sofyan AP. "Tinjauan Hukum Islam Tentang Jual Beli Via Telepon dan Internet", Al-Mizan 3, no. 1 Desember. 2007.

Kharofa, Ala' Eddin. Transactions in Islamic Law. Malaysia: A.S. Noorden, 1997.

Kementerian Agama RI, Al-Qur'an dan Terjemahnya. Jakarta: CV. Syamil Quran, 2015.

Malahayati, Rahasia Sukses Bisnis Rasulullah. Cet. I; Yogyakarta: Jogja Great! Publisher, 2010.

Maxmanroe, "3 Jenis Transaksi Jual Beli Online Terpopuler di Indonesia”, Blog Maxmanroe. https://www.maxmanroe.com/2014/01/3-jenis-transaksi-jual-belionline-terpopuler-di-indonesia.html (5 Januari 2015).

Misbahuddin, E-Commerce dan Hukum Islam. Cet. 1; Makassar: Alauddin University Press, 2012.

Moleong, Lexi J. Metodologi Penelitian Kualitatif.Cet. XXVII; Bandung: Remaja Rosdakarya, 2010

Republik Indonesia, Undang-undang RI Nomor 8 Tahun 1999 tentang Perlindungan Konsumen.

Suhendi, H. Hendi. Fiqh Muamalah. Cet. VI; Jakarta: PT Raja Grafindo Persada, 2010

Undang-Undang Nomor 11 Tahun 2008 tentang Informasi dan Transaksi Elektronik,

Widjaja, Gunawan dan Ahmad Yani, Hukum Tentang Perlindungan Konsumen, (Jakarta: Gramedia Pustaka Utama, 2000.

Zulham, Hukum Perlindungan Konsumen. Cet. I; Jakarta: Kencana Prenada Media

Website: Group, 2013.

Yusrie, M. "Kajian Undang-undang Perlindungan Konsumen dalam Perspektif Hukum Islam”, Ulumuddin 5, no. 3. Juli-Desember, 2009.

Roihanah, Rif'ah. "Perlindungan Hak Konsumen Dalam Transaksi Elektronik (Ecommerce)”, Justitia Islamica 8, no. 2 Juli-Desember. 2011. 